\title{
Something gone awry: unsolved mysteries in the evolution of asymmetric animal genitalia
}

\author{
Menno Schilthuizen ${ }^{1,2, *}$ \\ ${ }^{1}$ Naturalis Biodiversity Center, Darwinweg 2, 2333 CR Leiden, The Netherlands \\ ${ }^{2}$ Institute Biology Leiden, Leiden University, Sylviusweg 72, 2333 BE Leiden, The Netherlands \\ Submitted: May 28, 2012. Final revision received: July 30, 2012. Accepted: August 15, 2012
}

\begin{abstract}
The great diversity in genital shape and function across and within the animal phyla hamper the identification of specific evolutionary trends that stretch beyond the limits of the group under study. Asymmetry might be a trait in genital morphology that could play a unifying role in the evolutionary biology of genitalia. Here, I review the current knowledge on the taxonomic distribution, phylogenetic patterns, genetics, development, and ecology of asymmetric (chiral) genitalia. Asymmetric genitalia (male as well as female) have evolved from bilaterally symmetric ones (and sometimes vice versa), innumerous times in most animal taxa with internal fertilisation, and especially in Platyhelminthes, Arthropoda, Nematoda, and Chordata. In groups with asymmetric genitalia, chiral reversal (where species carry genitalia that are the mirror image of those in other, congeneric, species) is common, but antisymmetry (both mirror images present within a species) is rare. Although indications exist that, at least in insects, asymmetry evolves as a compensatory response to the evolution of maledominant mating positions, many mysteries remain. Main questions are: (i) is genital asymmetry developmental-genetically linked with other (visceral, external) asymmetries? (ii) is genital asymmetry usually correlated with a change in mating position? (iii) is asymmetry more likely to evolve in response to cryptic female choice or sexually-antagonistic coevolution? (iv) why is antisymmetry so rare and how does chiral reversal evolve? Based on an overview of the taxonomic patterns, I advocate a research program that makes use of the simple, binary nature of left-right asymmetry to test hypotheses for its evolution with experimental and comparative methods. I also provide tables with full or summarised data on (a) genital asymmetry across all animal phyla with internal fertilisation; (b) genera with dextral as well as sinistral species; (c) species with dextral as well as sinistral individuals; (d) genera with symmetric as well as asymmetric species; (e) species with symmetric as well as asymmetric individuals.
\end{abstract}

\section{Keywords}

Chirality; development; enantiomorphs; morphology; sexual selection; symmetry

*) E-mail: menno.schilthuizen@ naturalis.nl 


\section{Introduction}

Until three decades ago, the now blossoming field of animal genital evolution (Cordero and Eberhard, 2003; Leonard and Córdoba-Aguilar, 2010; Joly and Schmitt, 2010) did not yet exist. However, seminal empirical (Waage, 1979) and synthetic (Eberhard, 1985) publications, aided by developments in sexual selection theory (Eberhard, 1996; Rice, 1996; Arnqvist, 1998; Rowe et al., 2003; Hosken and Stockley, 2004) helped create a framework that allowed the field to develop rapidly. Today, bibliographic tools reveal a sharply rising output of over one hundred papers per year on the evolution of genitalia, which is beginning to approach the publication rates in the evolutionary biology of plant reproductive structures.

The field has benefited greatly from the wealth of available knowledge on morphological diversity in genitalia, brought together by taxonomists for those groups in which genitalia are routinely used in classification and identification (Eberhard, 1985). At the same time, however, the great diversity in genital shape and function across and within the animal phyla hamper the identification of specific evolutionary trends that stretch beyond the limits of the group under study. For example, the evolutionary processes involved in diversification of penile spines have been studied within, e.g., primates, Lepidoptera, Callosobruchus beetles and the melanogastergroup of Drosophila (Stockley, 2002; Kamimura, 2007; Rönn et al., 2007; Cordero and Miller, 2012), but the great disparity in morphological derivation prevent generalization across these groups.

One of the structural aspects of genitalia that can be studied in a meaningful way across animal taxa is asymmetry. This is a common and widespread feature in the genitalia of many animals (Ludwig, 1932; Huber et al., 2007; Kamimura and Iwase, 2010; Schilthuizen, 2011). At least seven (not all mutually exclusive) explanations have been put forward for the origin of asymmetry in genitalia (Huber et al., 2007; Schilthuizen, 2007), namely (i) morphological compensation for selected changes in mating position; (ii) male-female sexual arms races; (iii) cryptic female choice for asymmetric male genitalia; (iv) different functions for the left and right side; (v) one-sided reduction to save space and resources; (vi) functional constraints: to function properly, the separate parts of the genitalia need to connect in an asymmetric fashion; (vii) efficient packing: internal genitalia need to fit among other, asymmetric, organs in the body cavity. At least the first three of these may be of relatively general applicability.

Palmer (1996) has highlighted the relevance of studying partial or whole-body asymmetry in otherwise bilaterally symmetric animals. Not only have asymmetric shapes evolved repeatedly, in a wide variety of organ systems, and in representatives of almost all lineages of the Bilateria, but, more importantly, their "binary switch" nature allows generalizations that transcend the limits of individual taxa (Palmer, 2004). In this paper, I will advocate a research program that makes use of these benefits in investigating structural asymmetry in the evolution of animal genitalia. 


\section{Definitions and terminology}

Most, if not all, bilaterian animals carry certain morphological traits that are conspicuously asymmetric across the plane of body symmetry (I will not discuss fluctuating asymmetry, FA, the subtle variation around a mean of perfect symmetry; Van Valen, 1962). Well-known examples of conspicuous asymmetry include the orientation of the internal organs of mammals, the unequal claws in crabs and lobsters, the torsion of the head in flatfishes, and the coiling of much of the body in Gastropoda (Vermeij, 1975; Policansky, 1978; Okada et al., 1999; Schilthuizen and Davison, 2005; Friedman, 2008; Palmer, 2009). I will adopt Palmer's (2005) terminology, as follows. The two mirror images of an asymmetric (chiral) form are termed enantiomorphs. I will identify these as dextral and sinistral, although these terms do not provide any information about the actual shapes, except in the case of helical structures. In directional asymmetry (DA), only one of the two enantiomorphs is present (with the exception of very rare mutants, usually $\ll 1 \%$ ). In pure antisymmetry (AS), both enantiomorphs are present at equal frequencies. In biased AS, the more common enantiomorph is present at a frequency of more than $50 \%$ but less than $90 \%$. I will also discuss a few cases in which symmetry and conspicuous asymmetry occur within the same species, which I term DA/SYM dimorphism.

Here, I follow Eberhard (1985) and Huber et al. (2007) in defining male genitalia as "structures that are inserted in the female or that hold her near her gonopore during sperm transfer", and female genitalia as "those parts of the female reproductive tract that make direct contact with male genitalia or male products (sperm, spermatophores) during or immediately following copulation". I will limit myself to "structural asymmetry", i.e., asymmetry of genital structures that lie in the body's mid-plane or morphological dissimilarity between the left and right member of paired structures. Although possibly evolutionarily a springboard for structural asymmetry (Palmer, 2006), I will not discuss behavioural laterality of otherwise symmetric paired structures; e.g., handed penis use in the paired penises in Dermaptera (Kamimura and Iwase, 2010); removal of one pedipalp in male theridiid spiders (Knoflach and van Harten, 2000) and asymmetric positioning in the body cavity of otherwise bilaterally symmetric genital structures (e.g., rotation of the penis in leaf beetles [Verma and Kumar, 1972; Tiwary and Verma, 1989]).

\section{Taxonomic distribution}

Given the above definition of genitalia, the animal phyla referred to here are those in which direct contact between males and females is part of reproduction. This includes at least ten phyla, of which Platyhelminthes, Arthropoda, Nematoda, and Chordata display the most widespread genital asymmetry. This is listed in table S1 (online supplementary material), and a few striking examples are given below and in fig. 1.

In Arthropoda, genital asymmetry is extremely rare in Aranaea, present in a few groups within the Acari and Crustacea (especially Copepoda), relatively common 

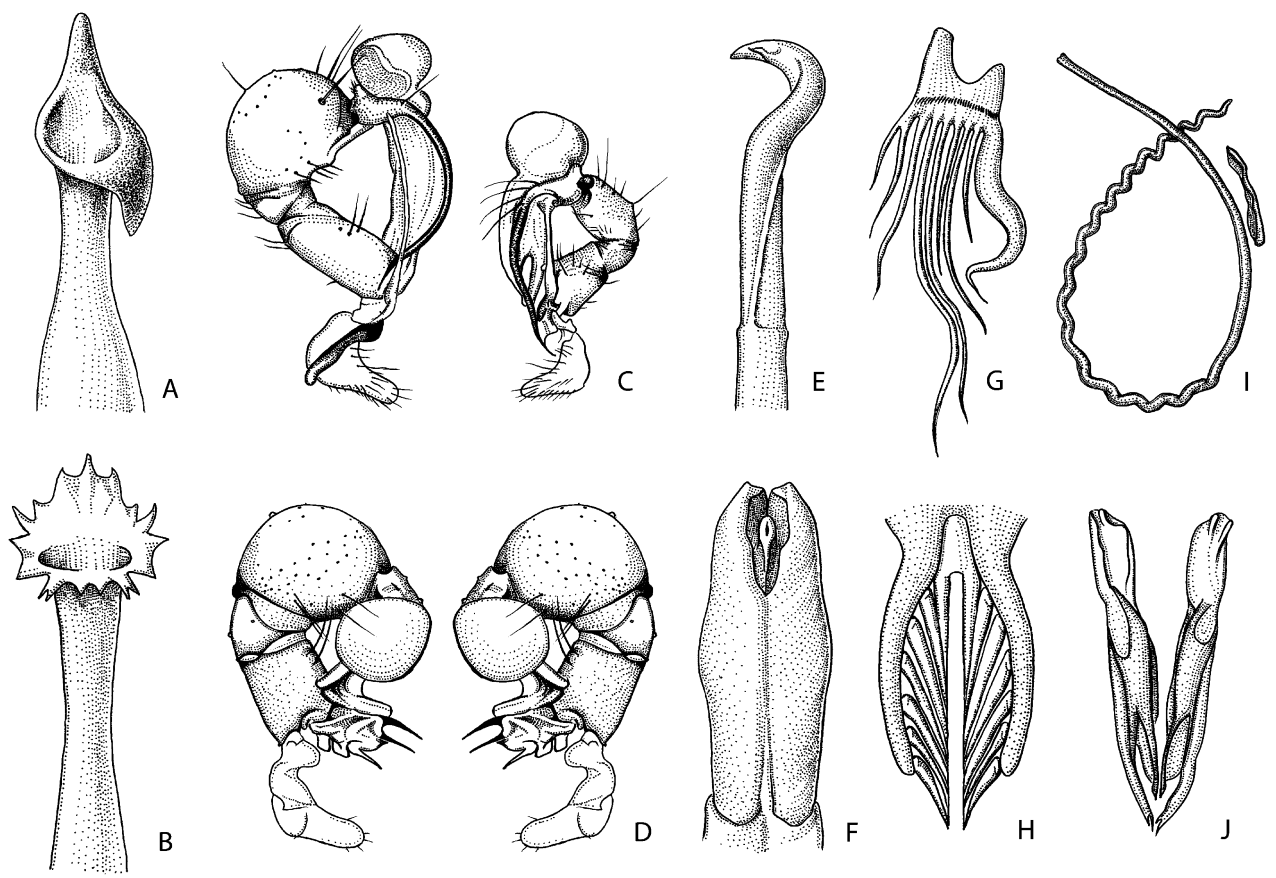

Figure 1. Pairwise examples of animal species with asymmetric (top row) male genitalia and their counterparts in related symmetric species (bottom row). (A) Limnodrilus cervix Brinckhurst, 1963: Tubificidae: Oligochaeta: Annelida (penis, after Stimpson et al., 1982); (B) Limnodrilus hoffmeisteri Claparède, 1862: Tubificidae: Oligochaeta: Annelida (penis, after Stimpson et al., 1982); (A-B) note, however, that the penes in Limnodrilus are paired; (C) Metagonia mariguitarensis (González-Sponga, 1998): Pholcidae: Araneae: Arthropoda (right and left palp, after Huber, 2000); (D) Metagonia tingo Huber, 2000: Pholcidae: Aranaea: Arthropoda (left and right palp, after Huber, 2000); (E) Sus scrofa L. 1758: Suidae: Mammalia: Chordata (penis, after Nickel-Schummer-Seiferle, 1960, in Prasad, 1970); (F) Dama dama (L. 1758): Cervidae: Mammalia: Chordata (penis, after Mandowsky, 1927, in Prasad, 1970); (G) Gieysztoria dodgei (Graff, 1911): Dalyelliidae: Rhabdocoela: Platyhelminthes (genital armature, after Graff, 1911); (H) Microdalyellia fairchildi (Graff, 1911): Dalyelliidae: Rhabdocoela: Platyhelminthes (genital armature, after Graff, 1911); (I) Tetrameres spirospiculum Pinto and Vicente, 1995: Tetrameridae: Spirurida: Nematoda (spicules, after Pinto and Vicente, 1995); (J) Oswaldocruzia tcheprakovae Ben Slimane and Durette-Desset, 1996: Molineidae: Strongylida: Nematoda (spicules, after Ben Slimane and Durette-Desset, 1996). All figured in ventrodorsal view, except C and D, which are figured in retrolateral and prolateral view, respectively.

in Opiliones, and exceedingly common in Insecta (table S1). Huber et al. (2007) summarise the insect data as follows: "In some insect orders or superorders, genital asymmetry is in the groundplan (e.g. Dictyoptera, Embiidina, Phasmatodea), in others it has evolved multiple times convergently (e.g. Coleoptera, Diptera, Heteroptera, Lepidoptera)." As an example, in Coleoptera, directional asymmetry in genitalia is found in 77 out of 177 families surveyed (Schilthuizen, in prep.). This includes very species-rich ones like Scarabaeidae, Staphylinidae, and Carabidae, and sometimes involves the female (e.g., in dorcine Lucanidae), but usually 
only the male genitalia, where asymmetry may be found in the midpiece and/or the parameres, but sometimes only in the endophallus or internal sac. Throughout these groups, asymmetry may be fixed at any taxonomic level: in individual species (Agathidium pilosum is the only asymmetric species within the large subfamily Leiodinae), in genera (e.g., Bibloporus and Euplectus within the Pselaphine staphylinids), or in entire tribes (e.g., Leiodidae: Ptomaphagini), subfamilies (e.g., Scarabaeidae: Glaphyrinae) or families (e.g., Mordellidae).

In Chordata, asymmetric penises commonly occur in at least four mammalian orders, in four fish families (Bisazza et al., 1998), in anseriform birds (which also have asymmetric vaginas [Brennan et al., 2007]), and in all snakes (table S1). Within the Ruminantia (except the deer, Cervidae), for example, the penis is always asymmetric, often coiled dextrally (chevrotains, Tragulidae), or on the left with a, sometimes coiled, urethral processus (other families). All species appear to be directionally asymmetric. The fact that Cervidae, the sister group to the musk deer (Moschidae), and terminal in the Ruminantia phylogeny (Hernández Fernández and Vrba, 2005), have a symmetric penis, suggests a return to symmetry from an asymmetric ancestor (Ludwig, 1932).

In male Nematoda, genital asymmetry commonly exists in the spicules and more rarely in the vulva (table S1). Spicules are (usually paired) rods that are inserted into the female vagina during copulation (Bird, 1971). In many (mostly parasitic) taxa, especially in the orders Ascaridida and Spirurida, left and right spicules are very unequal in size and shape (Chitwood and Chitwood, 1974; Anderson et al., 2009). Extreme cases include Tetrameres spirospiculum, in which one spicule is stout and alate, $0.15 \mathrm{~mm}$ long, whereas the other is approximately $1 \mathrm{~mm}$ long, slender, and "presents from its middle, towards the distal end, a progressive twisting that increases gradually in a corkscrew spiral" (Pinto and Vicente, 1995; fig. 1). In Caenorhabditis elegans, the spicula are almost symmetric (Hodgin, 1983).

\section{Intraspecific patterns and genetics}

As far as can be judged from the taxonomic literature, the vast majority of animal species with asymmetric genitalia show directional asymmetry (DA). Table 1 lists the small number of exceptional antisymmetric (AS) cases where both enantiomorphs occur within a species. Although good quantitative data are available for only a very small number of AS species, both pure AS and biased AS appear to exist. For even fewer species (e.g., Ciulfina, Chlorionidea) geographic variation in enantiomorph proportions has been documented (Giuglielmino and Bückle, 2010). A few cases of DA/SYM dimorphism have also been reported (table 1), but many of these may actually represent extreme fluctuating asymmetry (FA) or DA with occasional mutants, rather than true polymorphism.

The fact that in most species with strongly asymmetric genitalia, DA is the rule, suggests that the direction of asymmetry is usually genetically determined. This may even apply to AS species, since in the majority of cases, their close relatives (or 
Table 1.

Lists of taxa that might be suitable model organisms for studies of the evolution of asymmetric genitalia. Parts 1, 3 and 4 are selections from many more available groups (see also table S1); part 2, on the other hand, is an attempt at completeness. Please note that this table is divided over several pages, parts 2, 3 and 4 can be found there.

1. Genera with dextral as well as sinistral directional asymmetry (DA)

\begin{tabular}{lll}
\hline Genus & Higher taxon & References \\
\hline Haania (male) & Mantodea: Mantidae & Anisyutkin and Gorochov, 2004 \\
Ectobius (male) & Dictyoptera: Blatellidae & Bohn (1987); Brown (1975) \\
Phyllodromica (male) & Dictyoptera: Blatellidae & Bohn (1987) \\
Corixa (male) & Heteroptera: Corixidae & Huber et al. (2007) \\
Thaumastocoris (male) & Heteroptera: Thaumastocoridae & Noack et al. (2011) \\
Xylastodoris (male) & Heteroptera: Thaumastocoridae & Cassis pers. comm. \\
Octavius (male) & Coleoptera: Staphylinidae & Orousset (1988) \\
Arthromelus (male) & Coleoptera: Staphylinidae & Jeannel (1955) \\
Phalloceros (female) & Cyprinidontiformes: Poeciliidae & Lucinda (2008) \\
\hline
\end{tabular}

even conspecific populations) are DA (Nupponen, 2009; Giuglielmino and Bückle, 2010; Holwell and Herberstein, 2010). There are some exceptions to this pattern, however. In Metagonia spiders, for example, several species have AS female genitalia and symmetric male pedipalps, except $M$. mariguitarensis, which is DA in both female and male genitalia (Huber, 2004). Similarly, in phallostethid fish, the majority of species are AS for male priapum direction, with the exception of two dextral DA and two sinistral DA species. Phallostethids and Metagonia thus might conform with the pattern of genetic assimilation found in other structural asymmetries, where non-genetic AS evolves into genetic DA (Palmer, 2004). For most cases of AS in animal genitalia, however, AS is likely to be genetic and to arise from existing genetic DA via new mutations (what Palmer [2004] calls "conventional evolution"). Whether AS represent stable dimorphisms or intermediate stages in the transition from one enantiomorph to the other, remains to be investigated.

The observation (Burns, 1970; Lang and Orgogozo, 2012) of symmetric mutants of asymmetric species (Erynnis butterflies, Drosophila pachea) suggests that the genetic basis for the change between a symmetric and a chiral state may be relatively simple. However, classical genetics on the inheritance of genital symmetry and asymmetry in a single species appear not to have been done yet. Similarly, the genetics that dictate which of the two enantiomorphs the genitalia will develop into remain to be investigated in AS species (a study on handed penis use in paired penises in earwigs has, however, been carried out and showed no heritability, i.e., randomness; Kamimura and Iwase, 2010). One thing shines through, though: since chiral reversal of genital structure is not associated with the direction of chirality in the mouthparts, gut, wings or even the rest of the reproductive system (Bohn, 1987; Ahrens and Lago, 2008), at least part of the genetic pathway governing genital 


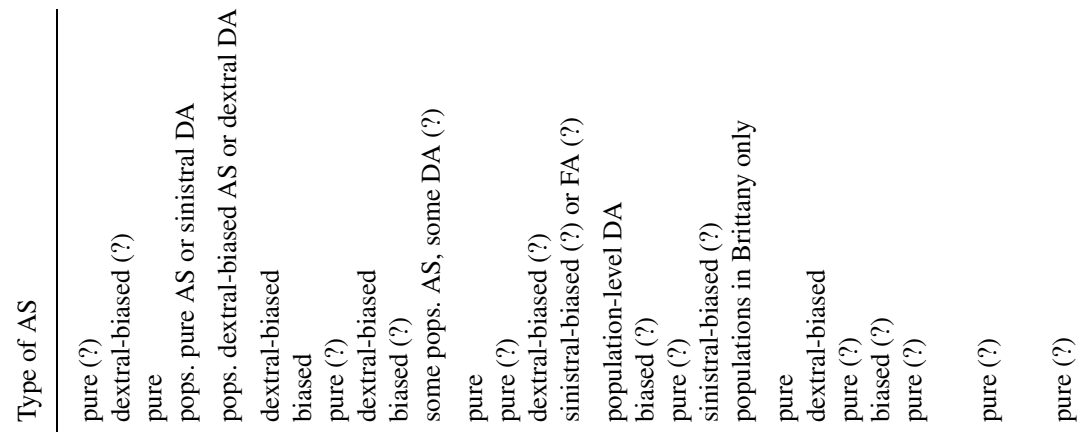

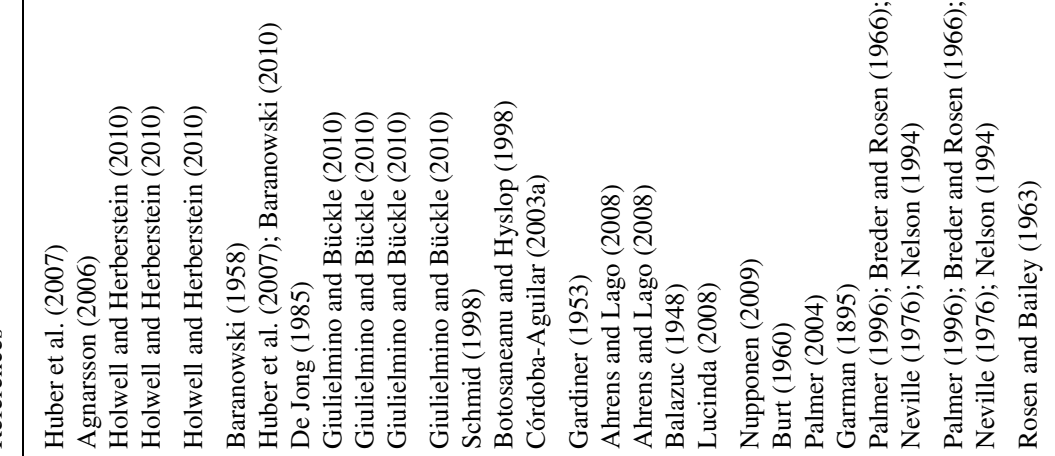

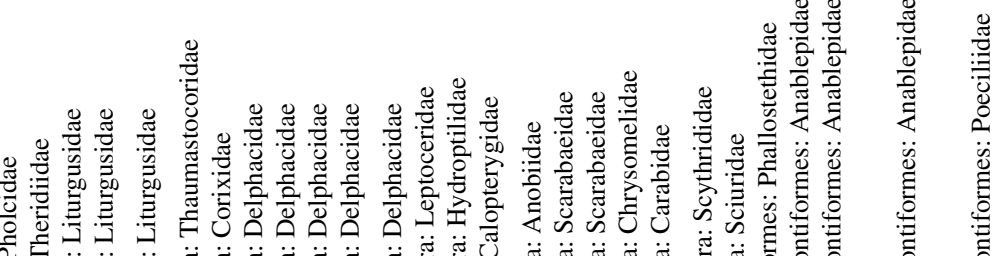

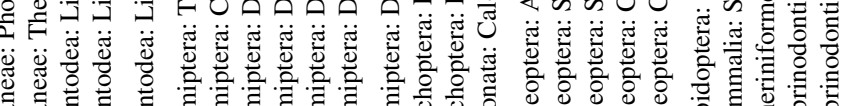

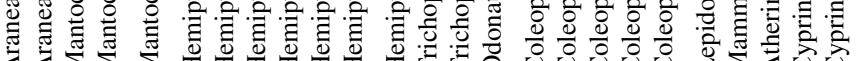

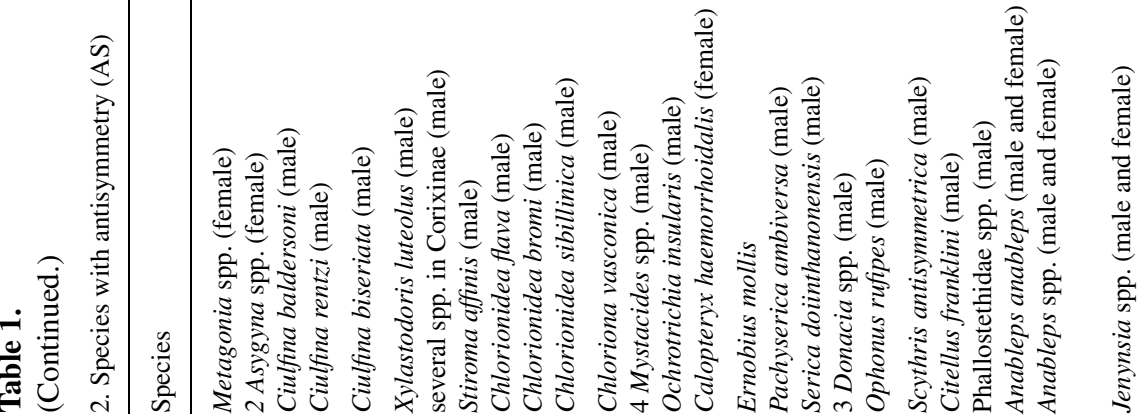


Table 1.

(Continued.)

3. Species with asymmetric as well as symmetric individuals

\begin{tabular}{|c|c|c|}
\hline Species & Higher taxon & References \\
\hline Drosophila pachea (male) & Diptera: Drosophilidae & Lang and Orgogozo (2012) \\
\hline Orthotrichia costalis (male) & Trichoptera: Hydroptilidae & Huber et al. (2007) \\
\hline Phylloicus spp. (male) & Trichoptera: Calamoceratidae & Huber et al. (2007) \\
\hline $\begin{array}{l}\text { Calopteryx haemorrhoidalis } \\
\text { (female) }\end{array}$ & Odonata: Calopterygidae & Córdoba-Aguilar (2003a) \\
\hline Erynnis funeralis (male) & Lepidoptera: Hesperiidae & Burns (1970) \\
\hline Erynnis propertius (male) & Lepidoptera: Hesperiidae & Burns (1970) \\
\hline Embidiina spp. (male) & Embidiina & Ross (2000) \\
\hline $\begin{array}{l}\text { Skleroprotopus ramuliferus } \\
\text { (male) }\end{array}$ & Diplopoda: Mongoliulidae & Mikhaljova and Korsós (2003) \\
\hline Poeciliidae spp. & Cyprinodontiformes: Poeciliidae & Rosen and Bailey (1963) \\
\hline
\end{tabular}

4. Genera with symmetric as well as directionally asymmetric (DA) species

\begin{tabular}{lll}
\hline Genus & Higher taxon & References \\
\hline Austrochorema & Trichoptera: Hydrobiosidae & Huber et al. (2007) \\
Quedius & Coleoptera: Staphylinidae & Lohse (1964) \\
Ptinus & Coleoptera: Anobiidae & Lohse (1969) \\
Notoxus & Coleoptera: Anthicidae & Bucciarelli (1980) \\
Cyclocephala & Coleoptera: Scarabaeidae & Lachaume (1985, 1992); Endrödi (1985) \\
Gonioctena & Coleoptera: Chrysomelidae & Mohr (1966) \\
Stenocarus & Coleoptera: Curculionidae & Freude et al. (1981) \\
Iolania & Hemiptera: Cixiidae & Hoch (2006) \\
Trichadenotecnum & Psocodea: Psocidae & Huber et al. (2007) \\
Microdaylellia & Rhabdocoela: Dalyelliidae & Graff (1913) \\
Pinanoetus & Acari:Anoetidae & Scheucher (1957) \\
Phalloceros & Cyprinodontiformes: Poeciliidae & Lucinda (2008) \\
\hline
\end{tabular}

asymmetry may be independent from the one involved in other body asymmetries (Hozumi et al., 2006; Spéder et al., 2006).

The genes that specify (parts of) the genitalia are known in many vertebrate and invertebrate model species (Haraguchi et al., 2000; Estrada and Sánchez-Herrero, 2001; Aspiras et al., 2011). However, although the ontogeny of genitalia has been studied in some detail, both in species with symmetric (Singh Pruti, 1924) and with asymmetric (Gardiner, 1953; Brown, 1975) genitalia, evo-devo studies that explain how asymmetric genital development is regulated, are still lacking.

\section{Patterns in male vs. female genitalia}

Based on evidence in, e.g., Dermaptera, Heteroptera, Lepidoptera, and Trichoptera, Huber et al. (2007) conclude that, in insect taxa, male asymmetries tend to evolve 
first, and female asymmetries evolve later, if at all. In Heteroptera, for example, taxa with female genital asymmetries are always nested within larger taxa in which male genital asymmetry exists, but rarely vice versa (Larsén, 1958). However, in the few spider groups where genital asymmetry is known, it is the other way around (see above for Metagonia). The pattern seen in insects (male asymmetry first) may apply to most other groups (Platyhelminthes, Annelida, Nematoda, Opiliones, Mammalia, Reptilia) as well (table S1).

Such observations are important, because patterns of male-first or male-only evolution may point in the direction of certain explanations for asymmetry. However, their morphological inaccessibility and lack of hard tissues make female genitalia understudied in morphology and underused in taxonomy (Eberhard, 1985; Huber, 2010). As a result, some patterns of apparent "male first" evolution, may actually reflect lack of knowledge of the female internal morphology rather than real evolutionary trends. This male bias is a general problem in genitalia research (Brennan et al., 2007; Huber et al., 2007), and any conclusions from patterns of asymmetry variation in male versus female genitalia should be drawn with this in mind.

\section{Genital asymmetry and mating position}

Of several possible explanations for the evolution of genital asymmetry, only one has been evaluated in detail, namely genital asymmetry as a morphological response to the change from a female-above to a male-above mating position in insects (selection on males for more control over the mating having resulted in this change). Huber and co-workers (Huber, 2004, 2010; Huber et al., 2007) have pointed out a series of apparently correlated evolutionary trends in the insects: (1) femaleabove mating positions are plesiomorphic, and male-above or "false male-above" (in which the male is on top but his abdomen contacts the female from below) are derived (Alexander et al., 1964; McAlpine, 1981); (2) morphological rotations of male genitalia and parts of the abdomen along their longitudinal axes are restricted to those taxa in which derived mating positions exist; (3) in derived, asymmetric mating positions (side-by-side or false male-above, for example), random-sided positions (in which there is behavioural flexibility in the direction in which the male abdomen bends during mating, and male genitalia are symmetric) evolve before fixed, one-sided positions with asymmetric genitalia; (4) symmetric genitalia are usually plesiomorphic with respect to asymmetric ones. This series of observations argues strongly for an evolutionary scenario in which genital asymmetry has evolved to accommodate morphologically the one-sided twists in the interaction between male and female genitalia.

In spider genitalia, however, very different patterns are found (see above): asymmetry is very rare, especially in males, is usually AS, and mating is never onesided. Huber et al. (2007) argue that this difference between insects and spiders is due to the paired nature of the spider male's genitalia, the pedipalps. In spiders, male-initiated changes in mating position are not likely, since any deviation from 
symmetric mating would jeopardise a male's ability to transfer both halves of the sperm he carries. This explains the female-first pattern in the few arachnid taxa in which genital asymmetry has evolved: asymmetry first arose in the internal female genitalia because of space constraints, and evolutionary responses took place in the pedipalps of males of only a few species.

\section{What remains to be investigated?}

The previous paragraphs summarise the available knowledge on the evolution of asymmetric genitalia in animals. Even after a cursory evaluation of the morphological and taxonomic literature, it is clear that interesting evolutionary patterns exist in many taxa, and at many different taxonomic levels. It is also clear that this potential has only just begun to be tapped, and that the phenomenon is open for much more ground-breaking comparative, evo-devo, and experimental approaches. Tables 1 and S1 provide lists of taxa that may be particularly suitable starting points for such investigations.

The work by Bernhard Huber and co-workers in insects and spiders is an impressive example of how large-scale patterns may be revealed by informal comparative work. The correlations that appear to exist, grosso modo, between mating position on the one hand and the evolution of asymmetric genitalia on the other, may be confirmed by similar large-scale investigations in non-Arthropods (Huber, 2004). In Nematoda, for example, copulation may be in a symmetrical position, venterto-venter, as in C. elegans (Loer and Kenyon, 1993), but in many species the male coils itself tightly around the female, resulting in the male spicules contacting the female vulva asymmetrically. Male coiling during copulation has been described for, e.g., species in the Rhabditida, Enoplida, Spirurida, Diplogastrina, Strongylida, and Ascaridida (Hope, 1974; Duggal, 1978; Ahmad and Jairajpuri, 1980; Kiontke et al., 2001; Ritter, 2001; De la Torre, 2003; Prior, 2003; Saeed, 2003). Although, like in insects (Huber et al., 2007), the chirality of asymmetric mating is not frequently mentioned for nematodes (Hope, 1974; Kiontke et al., 2001), it would be revealing to investigate whether, like in insects, asymmetric male genitalia are associated with fixed-direction copulatory coiling, and symmetric genitalia with venter-to-venter copulation or random-direction copulatory coiling. Similarly, the explanation that genital asymmetry is largely absent in the Araneae because they have dual copulatory organs, seems to be borne out by the absence of asymmetry in other taxa with paired intromittent organs (Kinorhyncha, Myriapoda, Branchiopoda, Ostracoda, Malacostraca, Chondrichtyes), although exceptions exist in the Oligochaeta and Squamata (table S1).

A further step in conducting comparative studies at a relatively deep taxonomic level would be to select phylogenetically well-resolved taxa that vary in genital asymmetry, and map male and female genital (a)symmetries on the phylogeny (Huber et al., 2007). Such studies will provide more accurate data on degrees of parallel evolution of asymmetries, male-first or female-first patterns, chiral reversal, and 
reversal to symmetry. More importantly, they will also allow a phylogenetically independent contrasts (Felsenstein, 1985; Garland et al., 1992) approach. In such an approach, correlations may be investigated between degree of genital asymmetry on the one hand, and traits that may be expected to co-vary with it under certain hypotheses (such as mating position and degree of polyandry, see Introduction), on the other.

If confirmed, a signal of male-first genital asymmetry and an association with a change from less male-dominant to potentially more male-dominant mating positions would suggest that genital asymmetry evolves as a response to male-female conflict in mating behaviour, as was suggested for insects (see above) in the work by Huber et al. (2007). However, the available data already indicate that additional factors must come into play as well. In many taxa, such as Coleoptera or Mammalia, mating positions appear to be conserved throughout much of the group, whereas genital asymmetry is not: it evolves repeatedly at all taxonomic levels, even in individual species within genera or species-groups. In such cases, the selection pressure may be a direct benefit of the asymmetric morphology itself, rather than a response to a behavioural change.

One possibility (hypothesis [ii] above) is sexually antagonistic coevolution in the mechanics of male-female genital interaction. Asymmetric male genitalia may be able to by-pass female controls over sperm fate, or they may allow repositioning of sperm in the female, thus effecting last-male sperm precedence. Some evidence for the latter process is available from the fly Dryomyza anilis, in which the female has three spermathecae that are asymmetrically located in the female's abdomen (Otronen and Siva-Jothy, 1991). Male genitalia show asymmetry in the claspers that they use to tap on the female's abdomen during mating, and the most asymmetric males were observed to have the highest reproductive success, which was explained by their being best able at repositioning their sperm in the female reproductive tract (Otronen, 1998). Conversely, asymmetric female genitalia may allow an escape from sensory exploitation by males. In calopterygid damselflies, such a mechanism seems to be at work in the asymmetry of female vaginal plate sensilla, which is interpreted as a counter-adaptation to the ejection of previous-male sperm by mechanical stimulation of the spermatheca by the male's (symmetric) aedeagus (Córdoba-Aguilar, 2003b).

Alternatively, asymmetry in male genitalia may be a character under selection from cryptic female choice (hypothesis [iii] above); like other novel male genital traits (Eberhard, 1996, 2011) the one-sidedness of tactile signals may hit a sensory bias in the females leading to a preference for more strongly asymmetric male genitalia. As far as I am aware, no experimental evidence for this hypothesis is available yet (though the results in Dryomyza anilis, mentioned above, could also be interpreted under a cryptic female choice scenario), but if such studies were to be conducted, they could benefit from the strict experimental frameworks developed for similar studies focusing on the more traditional genital traits (Eberhard, 2010, 2011). Mate-choice studies using males with symmetric genitalia rendered 


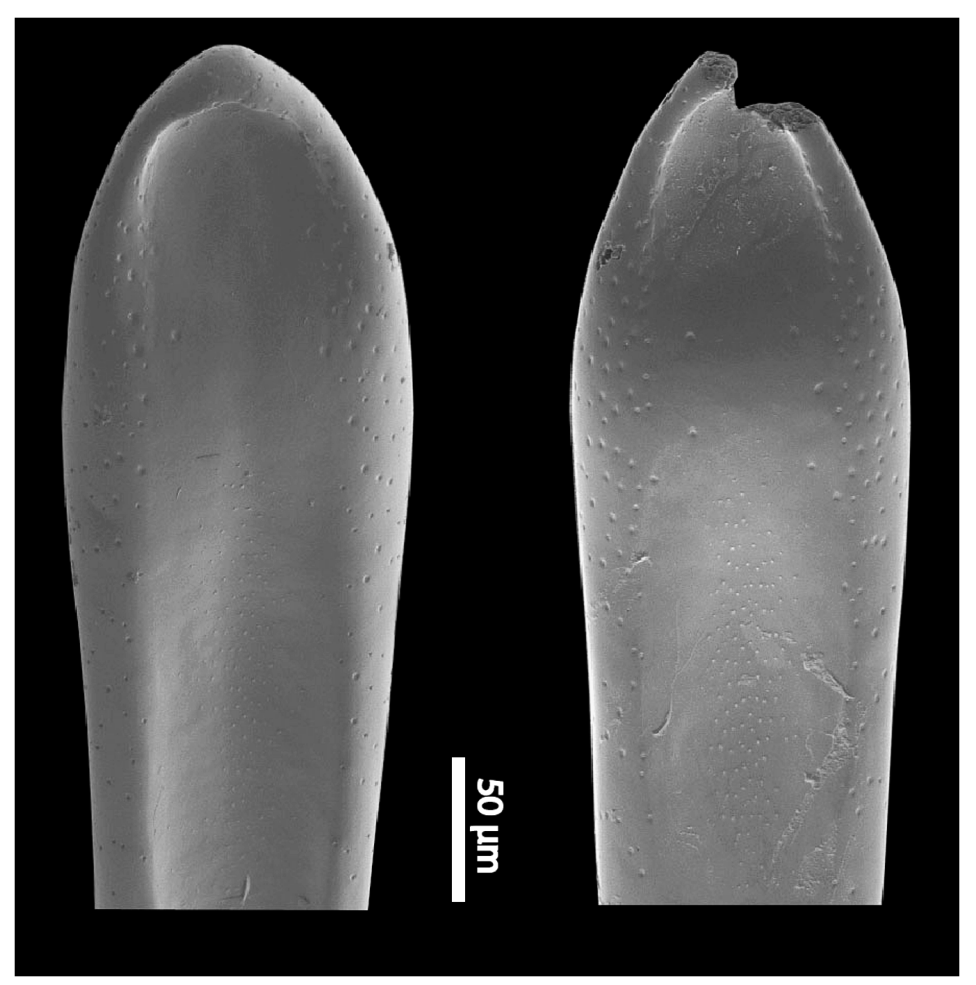

Figure 2. The apex of the penis of Catops tristis (Coleoptera: Leiodidae). Left, an intact structure; right, after rendering asymmetric by micro-laser ablation.

asymmetric or vice-versa using micro-laser ablation (Polak and Rashed, 2010) may be one fruitful approach (fig. 2), as would studies with naturally occurring mutants (Lang and Orgogozo, 2012).

One conundrum that such studies would need to address is how sexual selection cross the adaptive valley that may exist between strict symmetry and strong asymmetry (Otronen, 1998; Huber et al., 2007). If it is true that female mate choice would favour high levels of symmetry in males (Van Dongen, 2006), then this probably applies to genital features as well (see Koshio et al. [2007] for evidence in a lepidopteran), which might counteract any benefits of asymmetry. This may be one of the causes for the striking bimodality in groups of related species: genitalia often are either perfectly symmetric, or strongly asymmetric (fig. 1).

As mysterious as is the evolution of asymmetric genitalia per se, so too are the origins of chiral reversal and genetic antisymmetry in them. In many genera with asymmetric genitalia, the direction of DA asymmetry is reversed in some species compared with others (table 1). For dextrality to be replaced with sinistrality, a species must necessarily pass through a phase of antisymmetry. Such antisymmetric species are, however, extremely rare, which suggests that antisymmetry may be an evolutionarily unstable state. These problems have begun to be addressed in 
studies by Greg Holwell and co-workers on Ciulfina (Holwell et al., 2007). Like all Mantodea (Huber et al., 2007), this genus of Australian praying mantids displays strong asymmetry in the male genitalia (but female genitalia are symmetric), and a false male-above mating position. However, the chirality is very diverse (Balderson, 1978). Of the four described species (Holwell and Herberstein, 2010), C. klassi is always DA dextral, $C$. biseriata is predominantly DA dextral (but AS populations exist), C. rentzi is predominantly AS (but some DA sinistral populations exist), and C. baldersoni, finally, is always AS. In the dimorphic species, no distinct clinal variation in dextral:sinistral proportions was discernible. Mating tests showed that direction of chirality did not result in prezygotic isolation: interchiral pairs (dextral males mated with females from sinistral populations or vice versa) achieved genital coupling as easily as intrachiral pairs. However, the efficiency of sperm transfer in intrachiral relative to interchiral pairs has not been investigated yet.

Studies of genital antisymmetry might benefit from insights gained in work on the chirality of land snail coiling direction. Although DA sinistral species commonly occur in the (predominantly DA dextral) Pulmonata (Schilthuizen and Davison, 2005), antisymmetric species are exceedingly rare, which is probably caused by a mechanical incompatibility of the genitalia of enantiomorphs, leading to strong frequency-dependent selection against the rare morph in these hermaphrodites (Asami et al., 1998). In one of the few land snail groups in which antisymmetry is the rule (the subgenus Amphidromus s. str. [Schilthuizen et al., 2007; Sutcharit et al., 2007]), it is probable that the coiled structure of the genitalia allows interchiral pairs to circumvent sperm digestion and thus gain greater paternity (Schilthuizen et al., 2007; Schilthuizen and Looijestijn, 2009). Such processes may be harder to envisage in gonochorists (because both partners would not benefit simultaneously as they do in hermaphrodites), but they may still play a role in balancing genital antisymmetry and/or in facilitating chiral reversal.

\section{Conclusion}

I hope to have made a case that genital asymmetry and chirality are features worthy of study within the general framework of genital evolutionary biology. The phenomenon's binary nature and widespread occurrence allow generalisations across many taxa and a rich availability of suitable model groups. Since the study of genital asymmetry is in its infancy (even major synthetic works on genital morphology and evolution [Snodgrass, 1935; Eberhard, 1985; Leonard and Córboba-Aguilar, 2010] do not pay much attention to it), major progress in understanding the proximate and ultimate causes for asymmetry in animal genitalia can be made with experimental and comparative studies of suitable model groups. Judicious choice of these model groups, however, is essential, and ideally gravitates towards species for which experimental methods and genomic data are available, while at the same time belonging to higher taxa that vary in the expression of asymmetry, which allows multiple approached simultaneously. The tables 1 and $\mathrm{S} 1$ provide some starting 
points for the choice of model taxon, but obvious candidates are (i) the nannopteraspecies group of Drosophila; (ii) Rhabditida, including Caenorhabditis elegans; (iii) Ciulfina; but also (iv) Artiodactyla and (v) Delphacidae.

Finally, I would like to point out that such studies may have implications that transcend those of genital evolution alone. The organisation of most animals needs to maintain a delicate balance between, on the one hand, organs that interact with the external environment and require bilateral symmetry and, on the other hand, those that are less constrained by such demands and more free to develop asymmetrically (Levin, 1997; Icardo et al., 2002; Gao et al., 2011). It is thus remarkable that genitalia, straddling the demands of the internal and the external environment, so often seem to vary in which developmental scenario they follow. Understanding the developmental as well as the evolutionary genetics of these changes in genital form thus may provide further insights into how organ systems are incorporated into symmetry breaking.

\section{Supplementary material}

See Table S1 as supplementary material in the online edition of this journal, which can be accessed via http://www.brill.com/ab.

\section{Acknowledgements}

I gratefully acknowledge Erik van Nieukerken, Charles Fransen, Ronald Vonk, Luc Willemse, Oscar Vorst, the late L. Botosaneanu, Tom Bongers, Fernando Monroy, Jan Bruin, Gerry Cassis, Roy Wiles, Amélie Scheltema, Wim van der Putten, and Christian Baden for providing data and helping to find crucial information. Some of the information in this paper was based on unpublished reports by Leiden University students Thijmen Breeschoten, Paulien de Jong, Tamara Hoogenboom, Rick van Beek, and Melanie Meijer zu Schlochtern. Michal Polak (University of Cincinnatti) performed the laser-ablation shown in fig. 2. I am particularly grateful to the other members of the Naturalis chirality team (especially Rich Palmer, Barbara Gravendeel, Frietson Galis, and Tom van Dooren), for helping me shape my thoughts on the evolution of genital left-right asymmetry. This paper was much improved by the comments of Greg Holwell and an anonymous reviewer.

\section{References}

Agnarsson, I. (2006) Asymmetric female genitalia and other remarkable morphology in a new genus of cobweb spiders (Theridiidae, Araneae) from Madagascar. Biol. J. Linn. Soc., 87, 211-232.

Ahmad, I. \& Jairajpuri, M.S. (1980) Sex attraction and copulation in Chiloplacus symmetricus (Nematoda: Acrobelinae). Nematologica, 26, 139-148.

Ahrens, D. \& Lago, P.K. (2008) Directional asymmetry reversal of male copulatory organs in chafer beetles (Coleoptera: Scarabaeidae): implications on left-right polarity determination in insect terminalia. J. Zool. Syst. Evol. Res., 46, 110-117. 
Alexander, R.D. (1964) The evolution of mating behavior in arthropods. R. Ent. Soc. Lond. Symp., 2, 78-94.

Anderson, R.C., Chabaud, A.G. \& Wilmott, S. (2009) Keys to the Nematode Parasites of Vertebrates: Archival Volume. CABI, Wallingford.

Anisyutkin, L.N. \& Gorochov, A.V. (2004) Haania doroshenkoi, a new species of mantises from Cambodia (Mantina: Mantidae: Thespinae) and a case of mirror symmetry in the structure of the male genitalia of mantises. Russ. Ent. J., 13, 119-122.

Arnqvist, G. (1998) Comparative evidence for the evolution of genitalia by sexual selection. Nature, 393, 784-786.

Asami, T., Cowie, R.H. \& Ohbayashi, K. (1998) Evolution of mirror images by sexually asymmetric mating behavior in hermaphroditic snails. Am. Nat., 152, 225-236.

Aspiras, A.C., Smith, F.W. \& Angelini, D.R. (2011) Sex-specific gene interactions in the patterning of insect genitalia. Dev. Biol., 360, 369-380.

Balazuc, J. (1948) La tératologie des coléoptères et experiments de transplantation sur Tenebrio molitor L. Mém. Mus. Nat. Hist. Nat. Paris, 25, 1-193.

Balderson, J. (1978) Reversal of the phallic complex in the genera Ciulfina Giglio-Tos and Stenomantis Saussure (Mantodea: Mantidae: Iridopteryginae). Aust. J. Ent. Soc., 17, 235-239.

Baranowski, R.M. (1958) Notes on the biology of the royal palm bug, Xylastodoris luteolus Barber (Hemiptera, Thaumastocoridae). Annls. Ent. Soc. Am., 51, 547-551.

Ben Slimane, B. \& Durette-Desset, M.C. (1996) Two new species of Oswaldocruzia (Nematoda: Trichostrongylina, Molineoidea) parasitizing amphibians from Cameroon. Helminthologica, 33, 143-147.

Bird, A.F. (1971) The Structure of Nematodes. Academic Press, New York.

Bisazza, A., Rogers, L.J. \& Vallortigara, G. (1998) The origins of cerebral asymmetry: a review of evidence of behavioural and brain lateralization in fishes, reptiles and amphibians. Neurosci. Biobehav. Rev., 22, 411-426.

Bohn, H. (1987) Reversal of right-left asymmetry in male genitalia of Ectobiinae (Blattaria: Blattellidae) and its implications on sclerite homologization and classification. Entomol. Scand., 18, 293-303.

Botosaneanu, L. \& Hyslop, E.J. (1998) A systematic and biogeographic study of the caddisfly fauna of Jamaica (Insecta: Trichoptera). Bull. Inst. R. Sci. Nat. Belg. (Ent.), 68, 5-28.

Breder, C.M. \& Rosen, D.E. (1966) Modes of Reproduction in Fishes. TFH, Jersey City.

Brennan, P.L.R., Prum, R.O., McCracken, K.G., Sorenson, M.D., Wilson, R.E. \& Birkhead, T.R. (2007) Coevolution of male and female genital morphology in waterfowl. PloS ONE, 2, e418.

Brown, V.K. (1975) Development of the male genitalia in Ectobius spp. Stephens (Dictyoptera: Blattidae). Int. J. Insect Morph. Embryol., 4, 49-59.

Bucciarelli, I. (1980) Fauna d'Italia 17: Coleoptera Anthicidae. Calderini, Bologna.

Burns, J.M. (1970) Secondary symmetry of asymmetric genitalia in males of Erynnis funeralis and $E$. propertius (Lepidoptera: Hesperiidae). Psyche, 77, 430-435.

Burt, W.H. (1960) Bacula of North American mammals. Misc. Publ. Mus. Zool. Univ. Michigan, 113, 1-76, pl. I-XXV.

Chitwood, B.G. \& Chitwood, M.B. (1974) Introduction to Nematology. 2nd ed. University Park Press, Baltimore.

Cordero, C. \& Eberhard, W.G. (2003) Female choice of sexually antagonistic male adaptations: a critical review of some current research. J. Evol. Biol., 16, 1-16. 
Cordero, C. \& Miller, J.S. (2012) On the evolution and function of caltrop cornuti in Lepidoptera potentially damaging male genital structures transferrd to females during copulation. J. Nat. Hist., 46, 701-715.

Córdoba-Aguilar, A. (2003a) A description of male and female genitalia and a reconstruction of copulatory and fertilisation events in Calopteryx haemorrhoidalis (Van der Linden). Odonatologica, 32, 205-214.

Córdoba-Aguilar, A. (2003b) Predicting mechanisms of sperm displacement based on genital morphometrics in the Calopterygidae (Odonata). J. Ins. Behav., 16, 153-167.

De la Torre, M. (2003) Challenges for mass production of nematodes in submerged culture. Biotechnol. Adv., 21, 407-416.

Duggal, C.L. (1978) Copulatory behaviour of male Panagrellus redivivus. Nematologica, 24, 257268.

Eberhard, W.G. (1985) Animal Genitalia and Evolution. Harvard University Press, Cambridge.

Eberhard, W.G. (1996) Female Control: Sexual Selection by Cryptic Female Choice. Princeton University Press, Princeton.

Eberhard, W.G. (2010) Evolution of genitalia: theories, evidence, and new directions. Genetica, 138, 5-18.

Eberhard, W.G. (2011) Experiments with genitalia: a commentary. Trends Ecol. Evol., 26, 17-21.

Endrödi, S. (1985) The Dynastinae of the World. Junk, The Hague.

Estrada, B. \& Sánchez-Herrero, E. (2001) The HOX-gene Abdominal-B antagonizes appendage development in the genital disc of Drosophila. Development, 128, 331-339.

Felsenstein, J. (1985) Phylogenies and the comparative method. Am. Nat., 125, 1-15.

Freude, H., Harde, K.W. \& Lohse, G.A. (1981) Die Käfer Mitteleuropas 10. Bruchidae - Curculionidae I. Goecke \& Evers, Keltern.

Friedman, M. (2008) The evolutionary origin of flatfish asymmetry. Nature, 454, 209-212.

Gao, W., et al. (2011) Wdr18 is required for Kupffer's vesicle formation and regulation of body asymmetry in zebrafish. PloS ONE, 6, e23386.

Gardiner, P. (1953) The morphology and biology of Ernobius mollis L. (Coleoptera-Anobiidae). Trans. R. Ent. Soc. London, 104, 1-24.

Garland, T., Harvey, P.H. \& Ives, A.R. (1992) Procedures for the analysis of comparative data using phylogenetically independent contrasts. Syst. Biol., 41, 18-32.

Garman, S. (1895) Sexual rights and lefts. Am. Nat., 29, 1012-1014.

Giuglielmino, A. \& Bückle, C. (2010) Revision of Chlorionidea Löw (Hemiptera: Delphacidae) with the description of two new species from Italy, and comments on antisymmetry in male genitalia of Delphacidae. J. Nat. Hist., 44, 2737-2759.

Graff, L. von (1911) Acoela, Rhabdocoela und Alloeocoela des Ostens der Vereinigten Staaten von Amerika. Z. Wissensch. Zool., 99, 1-108.

Graff, L. von (1913) Turbellaria II. Rhabdocoelida. Friedländer, Berlin.

Haraguchi, R., Suzuki, K., Murakami, R., Sakai, M., Kamikawa, M., Kengaku, M., Sekine, K., Kawano, H., Kato, S., Ueno, N. \& Yamada, G. (2000) Molecular analysis of external genitalia formation: the role of fibroblast growth factor (Fgf) genes during genital tubercle formation. Development, 127, 2471-2479.

Hernández Fernández, M. \& Vrba, E.S. (2005) A complete estimate of the phylogenetic relationships in Ruminantia: a dated species-level supertree of the extant ruminants. Biol. Rev., 80, 269-302. DOI: $10.1017 / \mathrm{S} 1464793104006670$

Hoch, H. (2006) Systematics and evolution of Iolania (Hemiptera: Fulgoromorpha: Cixiidae) from Hawai'i. Syst. Ent., 31, 302-320. 
Hodgkin, J. (1983) Male phenotypes and mating efficiency in Caenorhabditis elegans. Genetics, 103, 43-64.

Holwell, G.I. \& Herberstein, M.E. (2010) Chirally dimorphic male genitalia in praying mantids (Ciulfina: Liturgusidae). J. Morphol., 271, 1176-1184.

Holwell, G.I., Ginn, S.G. \& Herberstein, M.E. (2007) Three new species of Ciulfina Giglio-Tos (Mantodea: Liturgusidae) from north-eastern Australia. Zootaxa, 1583, 23-35.

Hope, W.D. (1974) Deontostoma timmerchioi n. sp., a new marine nematode (Leptosomatidae) from Antarctica, with a note on the structure and possible function of the ventromedian supplement. Trans. Am. Micros. Soc., 93, 314-324.

Hosken, D.J. \& Stockley, P. (2004) Sexual selection and genital evolution. Trends Ecol. Evol., 19, 87-93.

Hozumi, S., Maeda, R., Taniguchi, K., Kanai, M., Shirakabe, S., Sasamura, T., Spéder, P., Noselli, S., Aigaki, T., Murakami, R. \& Matsuno, K. (2006) An unconventional myosin in Drosophila reverses the default handedness in visceral organs. Nature, 440, 798-802.

Huber, B.A. (2000) New world pholcid spiders (Araneae: Pholcidae): a revision at generic level. Bull. Am. Mus. Nat. Hist., 254, 1-348.

Huber, B.A. (2004) Evidence for functional segregation in the directionally asymmetric male genitalia of the spider Metagonia mariguitarensis. J. Zool., 262, 317-326.

Huber, B.A. (2010) Mating positions and the evolution of asymmetric insect genitalia. Genetica, 138, 19-25.

Huber, B.A., Sinclair, B.J. \& Schmitt, M. (2007) The evolution of asymmetric genitalia in spiders and insects. Biol. Rev., 82, 647-698.

Icardo, J.M., Rincón, J.M.G. \& Ros, M.A. (2002) Congenital heart disease, heterotaxia and laterality. Rev. Esp. Cardiol., 55, 962-974.

Jeannel, R. (1955) L'Édéage; initiation aux recherché sur la systématique des coléoptères. Publ. Mus. Natl. Hist. Nat. Paris, 16, 1-155.

Joly, D. \& Schmitt, M. (2010) Animal genitalia in evolution. Preface. Genetica, 138, 1-4.

Jong, K.A.G. de (1985) Aedeagal Mirror Symmetry in a Dutch Population of Stiroma affinis Fieber, 1866 (Homoptera Auchenorrhyncha, Delphacidae). K.A.G. de Jong, The Hague.

Kamimura, Y. (2007) Twin intromittent organs of Drosophila for traumatic insemination. Biol. Lett., 3, 401-404.

Kamimura, Y. \& Iwase, R. (2010) Evolutionary genetics of genital size and lateral asymmetry in the earwig Euborellia plebeja (Dermaptera: Anisolabididae). Biol. J. Linn. Soc., 101, 103-112.

Kiontke, K., Manegold, A. \& Sudhaus, W. (2001) Redescription of Diplogasteroides nasuensis Takaki, 1941 and D. magnus Völk, 1950 (Nematoda: Diplogastrina) associated with Scarabaeidae (Coleoptera). Nematology, 3, 817-832.

Knoflach, B. \& van Harten, A. (2000) Palpal loss, single palp copulation and obligatory mate consumption in Tidarren cuneolatum (Tullgren, 1910) (Araneae, Theridiidae). J. Nat. Hist., 34, 16391659.

Koshio, C., Muraji, M., Tatsuta, H. \& Kudo, S. (2007) Sexual selection in a moth: effect of symmetry on male mating success in the wild. Behav. Ecol., 18, 571-578.

Lachaume, R.-P. (1985) Dynastini 1. The Beetles of the World 5. Sciences Nat, Venette.

Lachaume, R.-P. (1992) Dynastidae americains. Beetles of the World 14. Sciences Nat, Venette.

Lang, M. \& Orgogozo, V. (2012) Distinct copulation positions in Drosophila pachea males with symmetric or left-right asymmetric external genitalia. Contr. Zool., 81, 87-94.

Larsén, O. (1938) Untersuchungen über den Geschlechtsapparat der aquatilen Wanzen. Opusc. Ent. Suppl., 1, 1-388. 
Leonard, J.L. \& Córdoba-Aguilar, A. (2010) The Evolution of Primary Sexual Characters in Animals. Oxford University Press, Oxford.

Levin, M. (1997) Left-right asymmetry in vertebrate embryogenesis. BioEssays, 19, 287-296.

Loer, C.M. \& Kenyon, C.J. (1993) Serotonin-deficient mutants and male mating behavior in the nematode Caenorhabditis elegans. J. Neurosci., 13, 5407-5417.

Lohse, G.A. (1964) Familie: Staphylinidae. In: H. Freude, K.W. Harde \& G.A. Lohse (Eds.) Die Käfer Mitteleuropas. Band 4, Staphylinidae I (Micropeplinae bis Tachyporinae), pp. 1-264. Goecke \& Evers, Krefeld.

Lohse, G.A. (1969) Familie: Anobiidae. In: H. Freude, K.W. Harde \& G.A. Lohse (Eds.) Die Käfer Mitteleuropas, Band 8, pp. 27-59. Goecke \& Evers, Krefeld.

Lucinda, P.H.F. (2008) Systematics and biogeography of the genus Phalloceros Eigenmann, 1907 (Cyprinodontiformes: Poeciliidae: Poeciliinae), with the description of twenty-one new species. Neotrop. Ichthyol., 6, 113-158.

Ludwig, W. (1932) Das Rechts-Links-Problem im Tierreich und beim Menschen. Springer, Berlin.

McAlpine, J.F. (1981) Morphology and terminology - adults. In: J.F. McAlpine, B.V. Peterson, G.E. Shewell, H.J. Teskey, J.R. Vockeroth \& D.M. Wood (Eds.) Manual of Nearctic Diptera, Vol. 1, 9-63. Agriculture Canada, Ottawa.

Mikhaljova, E.V. \& Korsós, Z. (2003) Millipedes (Diplopoda) from Korea, the Russian Far East, and China in the collection of the Hungarian natural history museum. Acta Zool. Acad. Scient. Hung., 49, 215-242.

Mohr, K.-H. (1966) Chrysomelidae. In: H. Freude, K.W. Harde \& G.A. Lohse (Eds.) Die Kafer Mitteleuropas 9, pp. 95-280. Goecke \& Evers, Krefeld.

Nelson, J.S. (1994) Fishes of the World. Wiley, New York.

Neville, A.C. (1976) Animal Asymmetry. Edward Arnold, London.

Noack, A.E., Cassis, G. \& Rose, H.A. (2011) Systematic revision of Thaumastocoris Kirkaldy. Zootaxa, 3121, 1-60.

Noordijk, J., Kleukers, R.M.J.C., van Nieukerken, E.J. \& van Loon, A.J. (2010) De Nederlandse biodiversiteit. Nederlandse Fauna 10. NCB Naturalis, Leiden and European Invertebrate Survey Nederland, Leiden.

Nupponen, K. (2009) Scythris antisymmetrica Nupponen, sp. n. from Central Spain, an example of antisymmetric male genitalia in the order Lepidoptera (Lepidoptera: Scythrididae). SHILAP Revta. Lepid., 37, 439-444.

Okada, Y., Nonaka, S., Tanaka, Y., Saijoh, Y., Hamada, H. \& Hirokawa, N. (1999) Abnormal nodal flow precedes situs inversus in $i v$ and inv mice. Mol. Cell, 4, 459-468.

Orousset, J. (1988) Insectes Coleopteres Staphylinidae Euasthetinae. Faune de Madagascar 71. Muséum National d'Histoire Naturelle, Paris.

Otronen, M. (1998) Male asymmetry and postcopulatory sexual selection in the fly Dryomyza anilis. Behav. Ecol. Sociobiol., 42, 185-191.

Otronen, M. \& Siva-Jothy, M.T. (1991) The effect of postcopulatory male behaviour on ejaculate distribution within the female sperm storage organs of the fly, Dryomyza anilis (Diptera: Dryomyzidae). Behav. Ecol. Sociobiol., 29, 33-37.

Palmer, A.R. (1996) From symmetry to asymmetry: phylogenetic patterns of asymmetry variation in animals and their evolutionary significance. Proc. Natl. Acad. Sci. USA, 93, 14279-14286.

Palmer, A.R. (2004) Symmetry breaking and the evolution of development. Science, 306, 828-833.

Palmer, A.R. (2005) Antisymmetry. In: B. Hallgrimmson \& B.K. Hall (Eds.) Variation, pp. 359-397. Elsevier, Amsterdam.

Palmer, A.R. (2006) Caught right-handed. Nature, 444, 689-691. 
Palmer, A.R. (2009) Animal asymmetry. Curr. Biol., 19, R473-R477.

Pinto, R.M. \& Vicente, J.J. (1995) Tetrameres (Tetrameres) spirospiculum n. sp. (Nematoda, Tetrameridae) from the buff-necked ibis, Theristicus caudatus caudatus (Boddaert) (Aves, Threskiornithidae). Mem. Inst. Oswaldo Cruz, 90, 615-618.

Polak, M. \& Rashed, A. (2010) Microscale laser surgery reveals adaptive function of male intromittent genitalia. Proc. R. Soc. Lond. B, 277, 1371-1376.

Policansky, D. (1978) Flatfishes and the inheritance of asymmetries. Behav. Brain Sci., 5, 262-266.

Prasad, M.R.N. (1974) Männliche Geschlechtsorgane. Handb. Zool., 8(51), 1-150.

Prior, J. (2003) Mansonella ozzardi (On-line), Animal Diversity Web. Accessed April 21, 2012 at http://animaldiversity.ummz.umich.edu/site/accounts/information/Mansonella_ozzardi.html

Rice, W.R. (1996) Sexually antagonistic male adaptation triggered by experimental arrest of female evolution. Nature, 381, 232-234.

Ritter, J. (2001) Anisakis simplex (On-line), Animal Diversity Web. Accessed April 21, 2012 at http:// animaldiversity.ummz.umich.edu/site/accounts/information/Anisakis_simplex.html

Rönn, J., Katvala, M. \& Arnqvist, G. (2007) Coevolution between harmful male genitalia and female resistance in seed beetles. Proc. Natl. Acad. Sci. USA, 104, 10921-10925.

Rosen, D.E. \& Bailey, R.M. (1963) The Poeciliid fish (Cyprinodontiformes), their structure, zoogeography, and systematics. Bull. Am. Mus. Nat. Hist., 126, 1-176.

Ross, E.S. (2000) Origin, relationships and integumental anatomy of the insect order Embiidina. Occ. Pap. Cal. Acad. Sci., 149, 1-53.

Rowe, L., Cameron, E. \& Day, T. (2003) Detecting sexually antagonistic coevolution with population crosses. Proc. R. Soc. Lond. B, 270, 2009-2016.

Saeed, S. (2003) Ancylostoma caninum (On-line), Animal Diversity Web. Accessed April 21, 2012 at http://animaldiversity.ummz.umich.edu/site/accounts/information/Ancylostoma_caninum.html

Scheucher, R. (1957) Systematik und Ökologie der deutschen Anoetinen. Beitr. Syst. Ökol. mitteleurop. Acarina, 1, 233-384.

Schilthuizen, M. (2007) The evolution of chirally dimorphic insect genitalia. Tijdschr. Ent., 150, 347354.

Schilthuizen, M. \& Davison, A. (2005) The convoluted evolution of snail chirality. Naturwissenschaften, 92, 504-515.

Schilthuizen, M. \& Looijestijn, S. (2009) The sexology of the chirally dimorphic snail species Amphidromus inversus (Gastropoda: Camaenidae). Malacologia, 51, 379-387.

Schilthuizen, M. (2011) Lopsided love. New Scientist, 2817, 42-45.

Schilthuizen, M., Craze, P.G., Cabanban, A.S., Davison, A., Gittenberger, E., Stone, J. \& Scott, B.J. (2007) Sexual selection maintains whole-body chiral dimorphism. J. Evol. Biol., 20, 1941-1949.

Schmid, F. (1998) The Insects and Arachnids of Canada, Part 7. - Genera of the Trichoptera of Canada and Adjoining or Adjacent United States. NRC Research Press, Ottawa.

Singh Pruti, H. (1924) On the post-embryonic development and homologies of the male genital organs of Tenebrio molitor L. (Coleoptera). Proc. Zool. Soc., 66, 857-868.

Snodgrass, R.E. (1935) Principles of Insect Morphology. McGraw-Hill, New York.

Spéder, P., Adam, G. \& Noselli, S. (2006) Type ID unconventional myosin controls left-right asymmetry in Drosophila. Nature, 440, 803-807.

Stockley, P. (2002) Sperm competition risk and male genital anatomy: comparative evidence for reduced duration of female sexual receptivity in primates with penile spines. Evol. Ecol., 16, 123137.

Sutcharit, C., Asami, T. \& Panha, S. (2007) Evolution of whole-body enantiomorphy in the tree snail genus Amphidromus. J. Evol. Biol., 20, 661-672. 
Tiwary, P.N. \& Verma, K.K. (1989) Studies on polymorphism in Callosobruchus analis (Coleoptera, Bruchidae) Part I - Characteristics of the phases. Entomography, 6, 269-290.

Van Dongen, S. (2006) Fluctuating asymmetry and developmental instability in evolutionary biology: past, present and future. J. Evol. Biol., 19, 1727-1743.

Van Valen, L. (1962) A study of fluctuating asymmetry. Evolution, 16, 125-142.

Verma, K.K. \& Kumar, D. (1972) The aedeagus, its musculature and 'retournement' in Aspidomorpha miliaris F. (Coleoptera, Chrysomelidae). J. Nat. Hist., 6, 699-719.

Vermeij, G.J. (1975) Evolution and distribution of left-handed and planispiral coiling in snails. Nature, 254, 419-420.

Waage, J.K. (1979) Dual function of the damselfly penis: sperm removal and transfer. Science, 203, 916-918. 